\title{
ECOSERV Hizmet Kalitesi Ölçüm Modeli ile Ekoturistlerin Çevresel Tutum ve Davranışları Arasındaki İlişki: Ekoçiftliklerde Bir Uygulama1
}

\author{
DOI: 10.26466/opus.505950 \\ *

\section{Zehra Türk ${ }^{*}$ - Fatma Çakı***}

* Öğr. Gör. Dr., Muğla Sıtkı Koçman Üniversitesi, Marmaris Tur.MYO, Marmaris/Muğla/Türkiye
E-Posta: zehraturk@mu.edu.tr
ORCID: 0000-0002-0769-1620
** Doç. Dr., Adnan Menderes Üniversitesi, Nazilli İ̈BF, Nazilli/Aydın/Türkiye
E-Posta: fatmacakir@adu.edu.tr
ORCID: $\underline{0000-0001-6574-2775}$

Öz

Ekoturist, ekoturizm aktivitelerinin ortaya çıkması ve yaygınlaşması ile birlikte ortaya çıkan ve ekoturizm faaliyetlerine özgü bir turist biçimidir. Çevreci, konfordan ziyade deneyim kazanma, doğanın bozulmamış yapısına saygıl, yerel dil, kültürel etkileşim hedefi olan ve maliyet beklentisi geri planda olan kişilerdir. Ekoturistler sahip oldukları özellikler, amaçları, turizm aktiviteleri, seyahatlerine ilişkin özellikleri, motivasyonları, tutum ve davranışları açısından diğer turist türlerinden ayrılmaktadır. Bu çalışmanın amacı, ekoturistlerin çevresel tutum ve davranışlar ile beklenen ve algilanan hizmet kalitesi arasındaki ilişkiyi ortaya koymaktır. Bu amaçla belirlenen hipotezler, korelasyon analizi ile test edilmiş ve anlaml sonuçlar elde edilmiştir. Araştırma sonucunda, beklenen hizmet kalitesi ile algılanan hizmet kalitesi arasında negatif yönlü ilişki ortaya çıkmıştır. Ayrıca ekoturistlerin çevresel tutum ve davranışları ile beklenen hizmet kalitesi arasında anlamlı bir ilişki olmadığı fakat ekoturistlerin çevresel tutum ve davranışları ile algılanan hizmet kalitesi arasında anlamlı bir ilişki olduğu tespit edilmiştir.

Anahtar Kelimeler: ECOSERV Hizmet Kalitesi, Çevresel Tutum, Çevresel Davranış

\footnotetext{
${ }^{1}$ Bu makale ilk yazarın doktora tezinden üretilmiştir.
} 


\title{
The Relationship Between ECOSERV Service Quality Measurement Model And Environmental Attitudes And Behaviors of Ecotourists: An Application on Ecofarms
}

\begin{abstract}
The ecotourist is a tourist who is unique to the ecotourism activities that emerges with the emergence and spread of ecotourism activities. These tourists are people who are environmentally friendly, give importance to experience, respect the nature's intact nature, have a target of local language and cultural interaction and have a low cost expectation. Ecotourists differ from other types of tourists in terms of their characteristics, objectives, tourism activities, travel characteristics, motivations, attitudes and behaviors. The aim of this study was to determine the relationship between ecotourists' environmental attitudes and behaviors and expected and perceived service quality. The hypotheses determined for this purpose were tested by correlation analysis and significant results were obtained. As a result of the research, a negative relationship was observed between expected service quality and perceived service quality. In addition, there was no significant relationship between ecotourists 'environmental attitudes and behaviors and expected service quality, but there was a significant relationship between ecotourists' environmental behaviors and perceived service quality.
\end{abstract}

Keywords: ECOSERV Service Quality, Environmental Attitudes, Environmental Behaviors 


\section{Giriş}

Kitlesel turizm hareketlerinin cezbedici özelliğini yitirmesi, teknolojinin gelişmesi, şehir hayatının aksine köy hayatına duyulan özlemin artması, doğa ile baş başa kalma isteği turizm hareketliliğinin değişmesini ve turist profilinin çevreci özelliklerinin ortaya çıkmasını sağlamıştır. Kitlesel turizmin doyuma ulaşması, turizm faaliyetlerine katılan bireylerin farklılık arayışında olmaları alternatif turizme yönelmeyi beraberinde getirmiştir. Alternatif turizm türlerinden olan ekoturizmde de hizmet kalitesi, işletmeler ve hizmet satın alan bireyler açısından büyük bir önem kazanmıştır.

Ekoturizm işletmeleri ekoturistler tarafından talep edilirken bu işletmelerin mevcut hizmet kaliteleri de merak edilir hale gelmiştir. Bu amaçla bu işletmelerin hizmet kalitesinin ölçülmesi ihtiyaç haline gelmiştir. Bu doğrultuda geliştirilen ECOSERV ölçeği ekoturizm hizmeti veren işletmelerin hizmet kalitesi ölçümünde kullanılması amacıyla Khan (1996) tarafından geliştirilmiştir Çalışma kapsamında ECOSERV ölçeği; ekoturizm faaliyetleri, çevresel tutum ve çevresel davranış ölçekleri ile birlikte kullanılmıştır. Bu bağlamda ekoturistlerin çevresel tutum ve çevresel davranışlarının, ekoturizm faaliyetlerine, ekoturizm işletmelerindeki hizmet kalitesine, hizmet alımı sonrasında oluşan memnuniyet veya değiştirme davranışına olan etkisi konularının kapsamlı bir şekilde ele alınması bu çalışmanın önemini artırmakla diğer çalışmalardan da farklılık göstermektedir.

Bu araştırma, Muğla İli Fethiye ve Ortaca İlçelerinde faaliyet gösteren ekoçiftlik işletmelerinden hizmet satın alan ekoturistlerin beklentilerini, algılarını, çevresel tutum ve davranışları arasındaki ilişkiyi belirlemek amacıyla yapılmıştır. Ekoturistlerin değerlendirdikleri ekoçiftlik işletmelerinin hizmet kaliteleri ECOSERV ölçeği ile belirlenmeye çalışılmıştır.

\section{Kavramsal Çerçeve}

Bu bölümde ekoturizm hizmet kalitesi ve ECOSERV ölçüm modeli ile ekoturistlerin çevresel tutum ve davranışlarına yönelik kavramsal açıklamalar yer almaktadır. Ayrıca ilgili yazında yer alan araştırmalara değinilerek, araştırmanın amacına uygun olarak geliştirilen hipotezlere de bu bölümde yer verilmektedir. 


\section{Ekoturizm Hizmet Kalitesi ve Ecoserv Ölçüm Modeli}

Hizmet kalitesi kavramı, işletmelerin başarı seviyelerini gösteren önemli bir gösterge olarak görülmektedir. Özellikle uzun vadede, kaynaklarını verimli kullanamayan ve kaliteli hizmet üretip sunamayan tesisler tüketici memnuniyetini sağlamada ve hedefledikleri kârlara ulaşmada sıkıntılar yaşamaktadırlar. Hizmet kalitesi günümüz örgütleri için oldukça önemli bir kavramdır. Hizmet kalitesi bir anlamda müşteri memnuniyetinin sağlanması noktasında kilit görev üstlenmektedir. Müşteri memnuniyetinin sağlanması, müşteri sadakatinin ön koşuludur ve sadık müşteriler, hizmet işletmelerinin müşteri paylarını ellerinde tutmalarına olanak sağlamaktadır. Dolayısıyla hizmet kalitesi müşteri memnuniyetinin sağlanması açısından önemlidir (Haciefendioğlu ve Koç, 2009, s.148).

ECOSERV ölçüm modelinin ortaya çıkması noktasında en önemli faktörlerden biri, ekoturizm kavramının artan önemidir. Ekoturizm, özellikle 1990'lı yıllardan itibaren, turizm sektörüne yeni bir turizm türü olarak giren ve sürekli olarak gelişme gösteren bir turizm tipidir. Küresel anlamda, doğa ve doğaya dair ilginin artması ve uluslararası turizm talebinin yapısal olarak değişime girmesi sonucunda, ekoturizm yeni nesil turistlerin tercih ettiği bir turizm türü olmuştur. Ekoturizm aktiviteleri, geleneksel turizm aktivitelerinden farklılaşan birtakım özelliklere sahip olduğu için de bu turizm süreçlerinde ortaya konulan hizmetin ölçülmesine yönelik yeni bir ölçüm modeli geliştirilmiştir (Ünüvar, 2017, s. 4)

Ekoturizm aktiviteleri temel olarak doğayı sevmek, doğadan zevk almak, çevresel ve kültürel değerleri korumak, incelemek, görmek ve çevreye ilişkin sürdürülebilirliği sağlamak noktasında özelleştiği için ekoturizm hizmet kalitesinin ölçümlenmesine yönelik model geleneksel hizmet ölçüm modellerinden farklılaşmaktadır. Ekoturizm; doğayı temel alan, biyolojik çeşitliliği önemseyen, yerel toplumsal refahın artırılması, sürdürülmesi ve eş zamanlı olarak yerel ekonomik kalkınmayı maksimize etmeye yöneliktir. Bu kapsamda da temel amaç ve strateji, kıt doğal kaynakların az kullanılması ve en yüksek verimin elde edilmesidir (Uslu vd., 2013, s.58). ECOSERV olarak adlandırılan hizmet ölçüm modeli, bu modelde yer alan boyutlar ve boyutlara ilişkin açılamalar aşağıdaki gibidir (Khan, 1996, s.72): 
- Fiziksel özellikler: Fiziksel tesisiler, ekipmanlar ve çalışan personelin görünümü,

- Güvenilirlik: Söz vermiş olduğu hizmeti doğru ve güvenli bir şekilde sunması,

- Heveslilik: Müşterilere ihtiyaç duyduğu tüm konularda yardım etmeye istekli olmak,

- Güven: Çalışanların doğru ve güvenilir hizmet verirken bilgi ve nezakete sahip olmaları,

- Empati: Müşterilerin istek ve ihtiyaçlarını yerine getirirken bireysel dikkat ve özen göstermeleri,

- Ekolojik fiziksel yapı: Müşterilerin istek ve beklentilerine yönelik fizikisel yapilar.

Araştırma kapsamında kullanılan ECOSERV ölçeği, temel olarak hizmet kalitesine yönelik beklenti şeklinde oluşmaktadır. Algılanan hizmet kalitesi ölçüm modeli de eklenerek araştırma kapsamına dâhil edilmiştir. ECOSERV çalışmaları incelendiğinde Khan (1996)'a göre sadece beklenti ölçeği yer alırken; son yıllarda yapılan çalışmalarda ECOSERV ölçeğinde beklenen ve algılanan hizmet kalitesinin bir arada araştırıldığını görmek mümkündür. Uslu vd., (2013)'nin çalışmalarında ECOSERV ölçeği kapsaminda beklenen ve algılanan hizmet kalitesi bir arada kullanılmıştır.

\section{Ekoturistlerin Çevresel Tutum ve Davranışları}

Ekoturist, ekoturizm aktivitelerinin ortaya çıkması ve yaygınlaşması ile birlikte ortaya çıkan ve ekoturizm faaliyetlerine özgü bir turist biçimidir. Çevreci, konfordan ziyade deneyim kazanma, doğanın bozulmamış yapısına saygıll, yerel dil, kültürel etkileşim hedefi olan ve maliyet beklentisi geri planda olan kişilerdir (Haberal, 2015, s. 44). Ekoturistler sahip oldukları özellikler, amaçları, turizm aktiviteleri, seyahatlerine ilişkin özellikleri, motivasyonları, tutum ve davranışları açısından diğer turist türlerinden ayrılmaktadır. Ekoturist diğer turist çeşitlerinden daha farklı olarak çevreye karşı hassas ve teknolojiye fazla ilgi göstermeyen yaklaşımlarıyla doğayı ve çevreyi koruyup kollayan doğa gezgini kişilerdir. Ekoturistler için dikkat çeken bir diğer husus ise, bilinmeyen yerleri görme, doğayı keşfetme, ziyaret etme, doğaya karşı hassas ve saygılı olma fonksiyonu da 
üstlenmesidir. Ekoturistler, doğayı kitle turizmine nazaran daha az olumsuzluğa sevk eden hassas ve duyarlı kişilerdir. Ekoturistlere bu yönleriyle bakmakla birlikte, ekoturizme yeni katılmayı bekleyen turistlere, doğanın tabii düzenini ve yapısına zarar vermeden, doğanın bozulmamış yapısından zevk alarak yararlanma telkini yapılmalıdır. Doğayı keşfedip gezmeye çıkan her turist ekoturist değildir. Doğa içerisinde yine doğaya yakın olan her turisti, ekoturistlerle karıştırmamak gerekir. Örneğin yaban hayatı gözlemciliği yapan ekoturistler, doğaya daha fazla duyarlılık gösterirken, farklı aktivitelerde bulunan ekoturistlerde aynı duyarlılık olmayabilir (Güngör, 2017, s. 5-6).

Mevcut doğa turizminin altında değerlendirilen ekoturizm, yapısıyla olduğu kadar bu faaliyeti icra eden ziyaretçileri ile de özel bir turizm branşı oluşturmaktadır. Ekoturizme katılan bireyler, gelir ve eğitim düzeyleri yüksek, doğaya karşı sorumlu ve ilgili, yeni yerler keşfetmek ve farklı kültürleri tanımak isteyen, nispeten üst yaş gurubundaki bireylerdir. Doğa bu bireylerin birçoğunun ilgi alanına girer ve sadece doğada bulunmak bile bu bireyler için tatmin yaratabilmektedir (Yücel, 2002).

Turizm çeşitleri ve aktiviteleri, turistlerin beklentilerinden meydana gelir ve turizme yönelen talepler bu beklentiler tarafından belirlenir. Ekoturizmde ise, ihtiyacı belirleyen ana unsurlar bozulmamış doğa, yerel doku ve kültürlerdir. Turistlerin bozulmamış doğaya olan ilgileri ve yerel kültürleri öğrenme istekleri bu turizme yönelmelerindeki ana nedenleri oluşturmaktadır. Bu noktadan değerlendirildiğinde ekoturizm doğa turizminin özel bir alt başlı̆̆ını oluşturmaktadır. (Demir ve Çevirgen, 2006, s.124).

Çevreye karşı hassas olan faaliyetler, ulaşım, konaklama tesisleri, yiyecek hizmetleri, hassas ve duyarlı tur operatörleri adına büyük ve etkili bir destek anlamına gelmektedir. Çevreci ve doğasever ziyaretçilerin dikkatini cezp etmek adına, günübirlik geziler düzenlemek, çevresel açıdan konuya duyarlı konaklama tesisleri, yerel hizmetler ve özellikler, kültürler, aktiviteler hakkında bilgi verme, tur operatörleri ile birlikte daha uzun gezilere çıkma fırsatları, bölgesel koruma aktiviteleri ile ilgili bilgi verilmesi gibi hususlar önemlidir (Erdoğan, 2003, s.197). Bu bağlamda ekoturizm hizmeti satın alan ekoturistlerin çevreye yönelik tutum ve davranışlarının araştırılması önem kazanmaktadır. 
Tutum; davranışların kavramların ve bir etkinin birleşiminden oluşan psikolojik bir yapıdır ve bir bireyin karşılaştığı olaylara karşı vermiş olduğu tepkilerin değerlendirilmesi olarak tanımlanabilir (Nilsson ve Küller, 2000, s.212). Bazı aktivitelere karşı bireylerin pozitif veya negatif tutumlar sergilemeleri sosyal psikolojinin tutum üzerine çalışmalarını gerekli kılmıştır. Bir bireyin karşılaşmış olduğu bir olay veya katılmaya istekli olduğu bir faaliyet karşısında sergileyecek olduğu davranışları belirleyecek olan olgu bireyin tutumlarıdır (Fennel ve Nowaczek, 2003, s.12).

Ekoturistlerin kesin çizgilerle çizilmiş belirli bir tutumları olmadığı bunun yanında ekoturistlerin tutumsal davranışlarının yumuşak ve sert karekteristik özellikleri olmak üzere iki ayrı gruba toplanabileceğini belirtmişlerdir (Fennel ve Nowaczek, 2003, s. 12).

Ekoturistler kendi faaliyetlerinden kaynaklanan doğaya zarar verici etkileri azaltma gayretlerinin yanı sıra doğayı korumacı ve doğanın bozulmamış yapısını sürdürülebilir kılma eğiliminde davranışlar sergilerler. Dünya Turizm Örgütü (WTO) ‘ne göre ekoturizm uygulamalarına katılan ekoturistlerin kendilerine ait çöpleri konakladıkları yerde bırakmadıkları hatta başkalarına ait çöpleri toplama eğiliminde oldukları belirtilmiştir. Ekoturistlerin geri dönüşümü mümkün olan ürünleri tercih ettikleri, vahşi doğada bulunan hayvanların doğal yaşam alanlarına müdahalede bulunmadıkları genel bir ifadeyle doğanın bozulmamış yapısının sürdürülebilirliği noktasında çevresel sorumluğa sahip bir bilinç doğrultusunda davranışlar sergiledikleri görülmektedir (www.wto.org).

Ekoturistlerin çevresel tutum ve çevresel davranışlarının sosyo demografik özelliklerden, ideolojik ve politik düşüncelerden, çevreye karşı sorumlu davranışlardan ve bunlara ilave olarak keyif alma unsurlarından oluştuğu söylenebilir. Ekoturistlerin sosyo-demografik özelliklerine bakıldığında daha yüksek derecede eğitimli oldukları, daha yüksek gelire sahip bireyler oldukları, liberal politik düşünceye sahip olup, saplantılı bir fikre sahip olmadıkları ve insan haklarının hayatın diğer bileşenlerinden daha baskın olduğunu düşünmektedirler. Bunlara ilave olarak yaş, eğitim, kentsel yaşam unsurları ile çevresel tutum arasında orta derecede bir ilişki olduğu görülmüştür. Ekoturistlerin cinsiyet, gelir ve mesleki kariyerleri ile çevresel tutum ve çevresel davranışları arasında çok kuvvetli olmasa da pozitif yönlü bir ilişki olduğu söylenebilir. Kadınların erkeklere 
oranla çevreye karşı daha fazla duyarlı oldukları, çevreyi daha az kirlettikleri, geri dönüşümü mümkün olan ürünleri tercih ettikleri fakat erkeklere oranla çevresel aktivitelere daha az katılım gösterdikleri görülmüştür (Khan, 1996, s.34).

\section{Yazın Taraması ve Araştırmanın Hipotezleri}

Literatürde Ekoserv hizmet kalitesi ölçüm modelini kullanan bir çok çalışmaya rastlanmıştır. Khan (2003) ABD'de ekoturistlere yönelik yaptığ1 araştırmada ekoturistlerin, doğal yapısı bozulmamış bir çevre beklentisi içinde oldukları, nazik, bilgilendirici, güvenilir ve samimi hizmet sunumu yapan işletmeleri tercih ettiklerini, buna ilave olarak çevreye uygun şekilde inşa edilmiş tesisleri daha çok tercih ettikleri sonucuna ulaşmıştır. Timothy ve Roh (2004) ise, ekoturistlerin hizmet kalite beklentisi ile memnuniyetleri arasında ve ekoturistlerin çevresel davranışı ile memnuniyetleri arasında bir ilişki olduğu sonucuna ulaşmışlardır. Rivera ve Croesb (2010) yaptıkları çalışmada, Galapagos adalarını ziyaret eden ekoturistlerin müşteri sadakatleri, fiyat, değer, müşteri tatmini, sunulan hizmet kalitesi boyutlarını ele alarak incelemiş, araştırma sonucunda Galapagos adalarını ziyaret eden ekoturistlerin tesadüfi ekoturist olmadıkları bu turizm aktivtisine daha önceki deneyimleri veya kendilerine yapılan bir tavsiye sonucunda katıldıklarını ve Galapalos adalarının ekoturistler için hedef bir destinasyon olduğu sonucuna ulaşmışlardır. Perkins ve Brown (2012) tatillerini Avusturalya'da geçiren turistler üzerinde yapmış oldukları araştırmada, turistlerin doğaya olan ilgilerini incelemişlerdir. Turizm işletmelerinin turistlere bozulmamış bir çevre ve farklı bir turizm deneyimi sunmak, kişisel özgürlükler üzerinde daha fazla kısıtlamalar yaparak hassas bölgelerde turistlerin olumsuz etkisini azaltmak, hassas olan destinasyonlarda taşıma kapasitesini dikkate almak gibi uygulamaların ödemeye istekli olmayan turistleri dahi bu işletmelere yönlendirebileceği sonucuna ulaşmışlardır. Nihalani (2012) çalışmasında, ekoturizm uygulamalarının hizmet kalitesi ve memnuniyet üzerindeki etkilerini analiz etmiş ve hizmet kalitesi ile müşteri memnuniyeti arasında ilişki bulmuştur. Bastič ve Gojčič (2012) araştırmalarında, turizm çalışanlarının ekolojik davranışlarının ve samimi yaklaşımlarının, su ve enerji tasarrufuna yönelik uygulamaların müşterilerin beklentilerine olumlu cevap verdiği, ekoturistlerin 
geldikleri ülkelerin kişi başına düşen gelirleri ile hizmet kalitesi beklenti düzeyleri arasında pozitif yönlü ilişki olduğu sonucuna ulaşmışlardır.

Said vd., (2013), Malezyada önde gelen ekoturizm destinasyonu olan Sarawak bölgesinde bulunan Niah National Park'daki hizmet kalitesini ölçmek için ECOSERV ölçeğini kullanmışlardır. Araştırma sonucunda, eko fiziksel boyut boyuta yönelik ekoturistlerin algıları beklentilerine göre daha yüksek çıkmıştır. Parkın zengin bioçeşitliliğe sahip olmasına rağmen hizmet kalitesindeki eksiklerden dolayı müşteri memnuniyeti sağlanmadığı sonucuna ulaşmışlardır. Liu vd., (2013) yaptıkları çalışmada, Tayvan'da ekoturistlerin tutum ve davranışları üzerinde ekoturizmde sunulan hizmet kalitesinin önemini araştırmışlardır. Çalışmanın sonucunda hizmet kalitesinin ekoturistlerin tutum ve davranışları üzerinde etkili olduğu ortaya çıkmış ayrıca hizmet kalitesinden memnun olan ekoturistlerin tekrar satın alma davranışında bulundukları sonucuna ulaşmışlardır.

Yusof vd., (2014) tarafından SERVQUAL ölçeği ile ekoturistlerin hizmet kalitesi beklentileri ve algıları arasında bir ilişki olup olmadığı araştırılmış ve uygulamaya katılan ekoturistlerin hizmet kalite beklentilerinin tüm boyutlarda hizmet kalite algılamalarından yüksek olduğu sonucu elde edilmiştir. Ayrıca yapılan bu araştırmada SERVQUAL ölçeğinin bu uygulamaya cevap verebilecek nitelikleri taşımadığı vurgulanmıştır. Noorazlan vd., (2015) yaptıkları çalışmada, Malezya'da turizm sektörünün gelecekteki büyümesine ve gelişmesine katkıda bulunması amacıyla ekoturistlerin hizmet kalite algıların belirlemek ve ECOSERV modelinin etkinliğini değerlendirmek amacıyla, açık hava eğlence programına katılan ekoturistler arasında hizmet kalitesini ölçmüşlerdir. Araştırmada ECOSERV boyutlarının güvenilirliği yüksek çıkmış, ölçeğin uygulanabilir olduğu sonucuna ulaşmışlardır. Kwayanti (2016) tarafından, ECOSERV ölçeği boyutlarının destinasyon seçimindeki etkisi araştırılmış ve anlamlı sonuçlar elde edilmiştir.

Ekoturizme yönelik Türkiye' de yapılan araştırmalar da bulunmaktadır. Altan (2006) tarafından Türkiye'deki ekoturizm uygulamalarına yönelik yapılan çalışmada, doğal ve kültürel zenginliklerin, farklı inançların, tarih zenginliğinin ve farklı kültürlerin Türkiye için büyük bir ekoturizm potansiyeli oluşturduğu, bu durumun turizm gelirlerine olumlu yansıdığı sonucuna ulaşılmıştır. Kuter ve Ünal (2009), ekoturizmin ekonomik ve 
sosyo-kültürel ve çevresel anlamda pozitif/negatif etkilerini ortaya koymak amacıyla sürdürülebilir gelişme, sürdürülebilirlik, sürdürülebilir turizm ve ekoturizm kavramlarını incelemiştir. Kaypak (2010) yaptığı araştırma ile ekolojik turizm türlerinin sürdürülebilirlik yönünden sahip olduğu önemin ne kadar yüksek olduğunu vurgulamaya çalışmıştır.

Güçer ve Kement (2015) Ayder yaylasındaki ekoturizm faaliyetlerine yönelik yaptıkları araştırmada, ekoturizm faaliyetlerine katılan bireylerin algıladıkları değerin müşteri tatminine, aktivite bağlılı̆̆ına, çevreye duyarlı davranışa ve müşteri tatmininin çevreye duyarlı davranışa etki ettiği sonuçlarına ulaşılmışlardır. Ayrıca aktivite bağlılığının müşteri tatminine ve çevreye duyarlı davranışa herhangi bir etkisinin olmadığı tespit edilmiştir. Ünüvar ve Aydın (2017), ECOSERV ölçeği ile Türkiye'de farklı coğrafi bölgelerdeki kıyı kesiminde yer alan ve ekoturizm potansiyeline sahip önemli turizm merkezlerini ziyaret etmiş olan turistlerin hizmet kalitesi alg1 ve beklentilerini araştırmıştır. Araştırma sonucunda, ekoturizm bölgelerini ziyaret etmiş turistlerin beklentileri algılarından yüksek çıkmış olup, ekofiziksel unsurlar boyutunun, diğer boyutlara göre turistler aç1sindan en önemli boyut olduğunu tespit etmişlerdir. Uslu vd., (2013) araştırmalarında ekoturizm potansiyeline sahip Kelebekler Vadisi'ni ziyaret eden turistlerin hizmet kalitesi beklenti ve algılarını ECOSERV ölçeği ile ölçmüşler ve turistlerin güvence ve güvenirlik alt boyutlarında beklentilerinin karşılandığı diğer boyutlarda karşılanmadığı sonucuna ulaşmışlardir.

Uluslararası ve ulusal literatürde yer alan ekoturizme yönelik yapılan çalışmalardan yola çıkarak aşağıdaki hipotezler geliştirilmiştir.

- H1:Ekoturistlerin çeoresel tutumlar ile beklenen hizmet kalitesi arasında anlamlı bir ilişki vardır.

- H2: Ekoturistlerin çevresel tutumları ile algılanan hizmet kalitesi arasinda anlamlı bir ilişki vardır.

- H3: Ekoturistlerin çeoresel davranışları ile beklenen hizmet kalitesi arasında anlamlı bir ilişki vardır.

- H4: Ekoturistlerin çevresel davranışları ile algılanan hizmet kalitesi arasinda anlamlı bir ilişki vardır. 


\section{Metodoloji}

Bu bölümde, araştırmanın amacı ve yöntemi, araştırmanın örneklemi ve kullanılan veri toplama aracı hakkında bilgiler yer almaktadır. Araştırma sonucu elde edilen verilerin değerlendirilmesi ve araştırmanın amacına uygun olarak oluşturulan hipotezlerin test edilmesi de bu bölümde yer almaktadır.

\section{Araştırmanın Amacı ve Yöntemi}

Araştırmanın amacı, ekoturizm çiftliklerinin hizmet kalitesini belirleme ölçeği olan ECOSERV ile ekoturistlerin çevresel tutum ve davranışları arasındaki ilişkiyi ortaya koymaktır. Bu amaçla, Muğla ili Fethiye ve Ortaca ilçelerinde faaliyet gösteren ekoçiftlik işletmelerini tercih eden ekoturistlerin hizmet kalite beklentileri ile algılanan hizmet kalitesi ECOSERV ölçeği ile tespit edilmeye çalışılmıştır.

Araştırmanın amacını gerçekleştirmek için alan araştırması yapılmıştır. Alan araştırmasında veri toplama yöntemi olarak nicel araştırma yöntemlerinden biri olan anket veri toplama yöntemi tercih edilmiştir. Araştırmada, demografik sorular, ECOSERV ölçeğine ait beklenti ve algı ifadeleri ile ekoturist faaliyetlerine yönelik tutum ve davranış ifadeleri yer almaktadır. ECOSERV ölçeği sadece beklenti ifadelerinin yer aldığı bir hizmet kalitesi ölçüm aracıdır. SERVQUAL ölçeğinden geliştirilen ECOSERV beklenti ifadelerine algı ölçeği de eklenerek hem beklenti hem algının ölçülmesi sağlanmıştır.

\section{Araştırmanın Örneklemi ve Veri Toplama Aracı}

Araştırmanın evreni, Muğla ili Fethiye ve Ortaca ilçelerinde yer alan ekoçifliklerden (birebir ekoturizm faaliyeti gösteren) hizmet satın alan yerli turistler olarak belirlenmiştir. Örneklem seçiminde, çiftliklerin birebir ekoturizm faaliyeti gösterip göstermemesi, araştırmaya gönüllü katılım sağlayıp sağlamamaları, veri toplama döneminde çiftliklerin faaliyet sürelerinin değişkenlik göstermesi (açık-kapalı olma durumu) ve tarım çiftliklerinin araştırma konusunu birebir karşılamaması dikkat edilen husus- 
lar olarak ele alınmıştır. Örneklem olarak, Muğla ili Fethiye ve Ortaca ilçesi ekoçiftliklerinde tatillerini geçiren yerli ekoturistler seçilmiştir. Anket formu işletme yöneticilerinden izin alınarak dağıtılmış ve toplanmıştır. Katılımcıların çoğunluğu ile yüz yüze görüşmeler yapılarak anket soruları ile ilgili fikirler alınmaya çalışılmıştır. Buğday Ekolojik Yaşamı Destekleme Derneği ve Muğla İlinde faaliyet gösteren ekoçiftlik yöneticileri ile yapılan görüşmeler neticesinde 2017 yılında ekoçiftlikleri tercih eden ekoturist sayısının yaklaşık 2000- 2200 kişi olduğu tespit edilmiştir. Örneklemin ana kütleyi temsil etme oranını belirlemek amacıyla yapılan hesaplama sonucunda 327 anketin evreni temsil etme yeteneği olduğu belirlenmiştir (www.surveysystem.com). Araştırmanın uygulamasında Fethiye ilçesinde Muğla bölgesinin en büyük ekoçiftlik işletmesi olan Pastoral Vadi ekoçiftliği ve Ortaca İlçesinde faaliyet gösteren Eski Köye Yeni Adet ekoçiftliğinden elde edilen veriler yer almıştır. Anket uygulamasında 350 adet anket dağıtılmış olup, geçerli kabul edilen anket sayısı 312 olmuştur.

Araştırmada veri toplama yöntemlerinden olan anket uygulaması seçilmiştir. Anket; çalışmayı kabul eden ekoturistlere yüz yüze görüşme yöntemiyle uygulanmıştır. Anket formunda, Khan (1996) tarafından oluşturulan ECOSERV beklenti ölçeği geliştirilerek beklenti ve algı ifadelerine yer verilmiştir. Ekoturisterin çevresel tutumlarını ölçmek amacıyla Krathwohl vd., (1973) tarafından geliştirilen Güven (2013) tarafından Türkçe' ye uyarlanmış olan “Çevresel Tutum Ölçeği” nden yararlanılmıştır. Ekoturistlerin çevresel davranışlarını ölçmek amacıyla Goldman vd., (2006) tarafından geliştirilen, Timur ve Yılmaz (2013) tarafından Türkçe' ye uyarlanmış olan “Çevresel Davranış Ölçeği”"nden yararlanılmıştır.

\section{Araştırma Bulgularının Değerlendirilmesi}

Anket uygulaması sonucunda elde edilen veriler IBM SPSS 22.0 istatistik paket programı kullanılarak analiz edilmiştir. Araştırma amacına yönelik oluşturulan hipotezler \%95 güven aralığında değerlendirilmiştir. Araştırma sonucu elde edilen verilerin normal dağılıp dağılmadığını test etmek amacıyla Kolmogorov-Smirnov analizi gerçekleştirilmiş ve elde edilen sonuçlar doğrultusunda uygun testler kullanılmıştır. Ayrıca değişkenler arasındaki ilişkiler korelasyon analizi ile test edilmiştir. 


\section{Demografik Veriler}

Araştırmaya katılan ekotüketicilerin cinsiyet, yaş, eğitim durumu, meslek ve aylık gelir gibi demografik özellikleri aşağıda Tablo 2’ de gösterilmektedir.

Tablo 1. Araştırmaya Katılanların Demografik Özellikleri

\begin{tabular}{|c|c|c|c|}
\hline \multicolumn{2}{|c|}{ Demografik Özellikler } & \multirow{2}{*}{$\begin{array}{c}\mathbf{N} \\
153\end{array}$} & \multirow{2}{*}{$\begin{array}{l}\mathbf{\%} \\
49\end{array}$} \\
\hline Cincinet & Kadın & & \\
\hline Cinsiyet & Erkek & 159 & 51 \\
\hline \multirow{5}{*}{ Yaş } & 29 yaş ve altı & 63 & 20,2 \\
\hline & $30-39$ yaş & 51 & 16,3 \\
\hline & $40-49$ yaş & 120 & 38,5 \\
\hline & $50-59$ yaş & 57 & 18,3 \\
\hline & 60 yaş ve Üstü & 21 & 6,7 \\
\hline \multirow{4}{*}{ Eğitim Durumu } & Yüksekokul ve altı & 24 & 7,7 \\
\hline & Lisans & 216 & 69,2 \\
\hline & Yüksek Lisans & 51 & 16,3 \\
\hline & Doktora & 21 & 6,7 \\
\hline \multirow{5}{*}{ Meslek } & Serbest Meslek & 156 & 50,0 \\
\hline & Memur & 99 & 31,7 \\
\hline & Ev Hanımı & 12 & 3,8 \\
\hline & Öğrenci & 18 & 5,8 \\
\hline & Diğer & 27 & 8,7 \\
\hline \multirow{5}{*}{ Aylık Gelir } & 2499 TL ve alt1 & 15 & 4,8 \\
\hline & 2500-3999 TL & 12 & 3,8 \\
\hline & 4000-5999 TL & 53 & 20,2 \\
\hline & 6000-7999 TL & 108 & 34,6 \\
\hline & 8000 TL ve üstü & 114 & 36,5 \\
\hline
\end{tabular}

Tablo 1'de görüldüğü gibi ankete katılanların \%49'u kadın \%51'i erkektir. Tüm gelen turist sayıları dikkate alındığında bu oranların ana kütleyi temsil ettiği görülmektedir. Yaş değişkeniyle ilgili dikkat çeken bir durum 4049 yaş aralığındaki ekoturist sayısının fazlalığıdır. Ekoturizm nispeten çevreye daha duyarlı, daha eğitimli, daha kültürlü ve yaşı oturmuş insanların ilgi alanına girmektedir. Genç nüfusun daha çok hareketli ve eğlenceli mekanlar aradığı yapılan başka çalışmalarda ortaya çıkmıştır. Yine çalışmada yoğunluğun orta yaş olarak çıkması beklentilere uygundur. Eğitim durumunda da yoğunluk üniversite ve üstü olarak görülmektedir. Buradan da ekoturizmi tercih edenlerin eğitimli kişiler olduğu açık bir şekilde ortaya çıkmıştır. Ekoturizm bir bilinç turizm olup, daha çok eğitimli 
ve kültürlü insanların katıldığı bir turizm çeşididir. Meslek açısından ise serbest meslek ve memur kesimi ağır basmaktadır. Serbest meslek ankete katılanların yarısını oluşturmaktadır. Yüz yüze yapılan görüşmelerde elde edilen bilgilere göre serbest meslek grubunda olanların büyük kısmı avukat, doktor, mimar, esnaf tarzı gruplardan oluşmaktadır ki, bu da yukarıda bahsedilen cümleleri doğrular niteliktedir. Yine aylık gelirin katılımcıların büyük bölümde 6000 ve üzeri olması da yukarıdaki tüm sonuçları teyit etmekte olup, çalışmanın da tutarlılığı açısından önemli bir göstergedir. Sonuç olarak ekoturizmi tercih edenler genellikle gelir düzeyi yüksek olan bireylerdir.

\section{Güvenilirlik Analizi ve Tanımlayıcı Ístatistikler}

Araştırmada kullanılan ölçeklere ilişkin güvenilirlik analizi sonuçları aşağ1daki tabloda yer almaktadır.

Tablo 2. Ölçeklere İlişkin Güvenilirlik Analizi Tablosu

\begin{tabular}{lcc}
\multicolumn{1}{c}{ Değişkenler } & Cronbach $\boldsymbol{\alpha}$ katsayısı & Madde Sayısı \\
\hline ECOSERV Beklenti Ölçeği & 0,950 & 34 \\
ECOSERV Algı Ölçeği & 0,988 & 34 \\
Çevresel Tutum Ölçeği & 0,720 & 5 \\
Çevresel Davranış Ölçeği & 0,801 & 3 \\
\hline
\end{tabular}

ECOSERV beklenti ölçeğine yönelik ifadelerin güvenilirlik analizi değeri (Cronbach's Alpha) 0,950 çıkmıştır. ECOSERV alg1 ölçeği güvenilirlik analizi değeri ise 0,988'dir. Çevresel Davranış Ölçeği güvenilirlik analizi değeri 0,801'dir. Cronbach's Alpha değeri 0,80' in üzerinde ise yüksek derecede güvenilir bir ölçektir (Kalaycı, 2010, s. 405). Çevresel tutum ölçeği güvenilirlik analizi değeri 0,720'dir. Cronbach's Alpha değeri 0.60 - 0.80 aralığında ise ölçek oldukça güvenilirdir (Kalaycı, 2010, s.405). Araştırmada kullanılan ölçeklerin güvenilir olduğu sonucuna ulaşılmıştır.

ECOSERV beklenti ve algı ölçeği alt boyutlarını tespit etmek amacıyla açıklayıcı faktör analizi yapılmış ve Varimax dönüştürme yöntemi kullanılmıştır. ECOSERV beklenti ölçeği alt grupları için elde edilen faktör analizine Tablo 4' de yer verilmiştir. Beklenti düzeyi değişkenine ilişkin faktör 
analizi çerçevesinde öncelikle veri setinin faktör analizi uygunluğu değerlendirilmiştir. KMO testi ve Bartlett testi sonuçları Tablo 4'de yer almaktadır.

Tablo 3. ECOSERV Beklenti Düzeyi Faktör Analizi Sonuçları

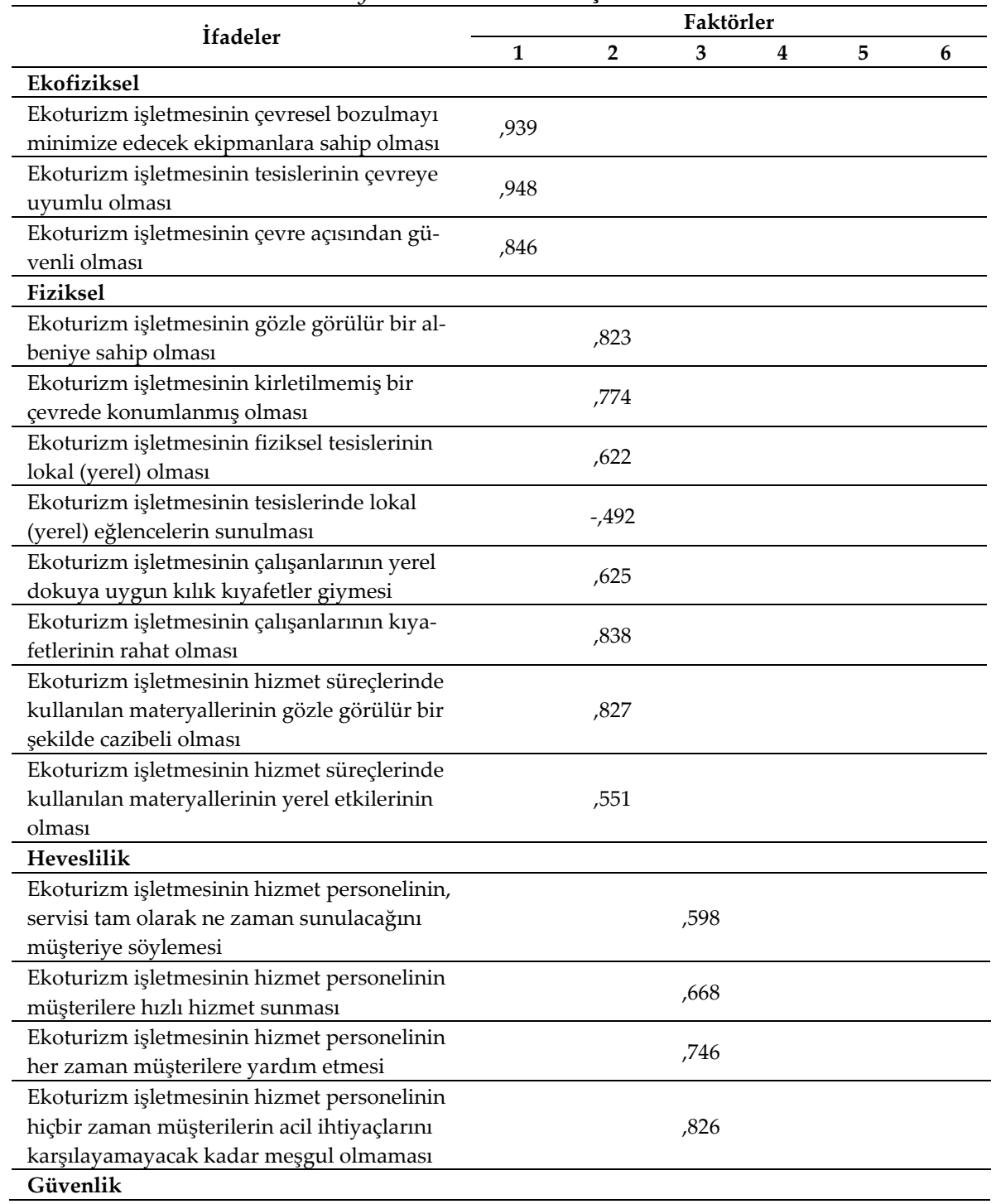




\begin{tabular}{|c|c|c|c|c|c|}
\hline $\begin{array}{l}\text { Ekoturizm işletmesinin bir şeyi yapacakla- } \\
\text { rına söz verdiklerinde söz verdikleri za- } \\
\text { manda eylemi gerçekleştirmiş olması }\end{array}$ & & & 860 & & \\
\hline $\begin{array}{l}\text { Ekoturizm işletmesinin, müşterilerinin prob- } \\
\text { lemlerini çözmek için samimi çaba göster- } \\
\text { mesi }\end{array}$ & & & 844 & & \\
\hline $\begin{array}{l}\text { Ekoturizm işletmesinin hizmetinin ilk se- } \\
\text { ferde en doğru şekilde sunması }\end{array}$ & & & ,825 & & \\
\hline $\begin{array}{l}\text { Ekoturizm işletmesinin hizmeti söz verilen } \\
\text { zamanda sunması }\end{array}$ & & & 810 & & \\
\hline $\begin{array}{l}\text { Ekoturizm işletmesinin hatasız kayıtların } \\
\text { oluşması için ısrarcı olması }\end{array}$ & & & 719 & & \\
\hline \multicolumn{6}{|l|}{ Empati } \\
\hline $\begin{array}{l}\text { Ekoturizm işletmesinin müşteriye bireysel } \\
\text { dikkat ve özen göstermesi }\end{array}$ & & & & ,898 & \\
\hline $\begin{array}{l}\text { Ekoturizm işletmesinin çalışma saatlerinin } \\
\text { tüm müşterileri için uygun olması }\end{array}$ & & & & ,894 & \\
\hline $\begin{array}{l}\text { Ekoturizm işletmesinin çalışanlarının müşte- } \\
\text { rilere bireysel ilgi göstermesi }\end{array}$ & & & & 866 & \\
\hline $\begin{array}{l}\text { Ekoturizm işletmesinin müşterilerin kal- } \\
\text { binde en iyi etkiye sahip olması }\end{array}$ & & & & 811 & \\
\hline $\begin{array}{l}\text { Ekoturizm işletmesinin çalışanlarının, müş- } \\
\text { terilerin spesifik ihtiyaçlarını anlayabilmesi }\end{array}$ & & & & 778 & \\
\hline \multicolumn{6}{|l|}{ Güvence } \\
\hline $\begin{array}{l}\text { Ekoturizm işletmesinin çalışanlarının müşte- } \\
\text { rilerin her tip sorusuna cevap verecek bil- } \\
\text { giye sahip olması }\end{array}$ & & & & & 772 \\
\hline $\begin{array}{l}\text { Ekoturizm işletmesinin çalışanlarının davra- } \\
\text { nışlarının müşterilere güven aşılaması }\end{array}$ & & & & & 662 \\
\hline $\begin{array}{l}\text { Ekoturizm işletmesinin müşterilerinin işlem- } \\
\text { lerinde kendilerini güvende hissetmesi }\end{array}$ & & & & & ,680 \\
\hline $\begin{array}{l}\text { Ekoturizm işletmesinin çalışanlarının müşte- } \\
\text { rilere karşı sürekli olarak nazik olması }\end{array}$ & & & & & ,574 \\
\hline $\begin{array}{l}\text { Ekoturizm işletmesinin çalışanlarının gerekli } \\
\text { olan bilgileri müşterilere aktarır olması }\end{array}$ & & & & & 649 \\
\hline $\mathrm{KMO}$ & 0,886 & & & & \\
\hline Bartlett & $\mathrm{p}<0,05(0,000)$ & & & & \\
\hline Bartlett $x^{2}$ & 9585,644 & & & & \\
\hline Özdeğer & $11,481 \quad 4,127$ & 2,703 & 1,739 & 1,557 & 1,196 \\
\hline Varyansı Açıklama Oranı \% & 38,271 & 9,009 & 5,796 & 5,190 & 3,986 \\
\hline Toplam Varyansı Açıklama Oranı \% & 76,010 & & & & \\
\hline Cronbach's Alpha (Tüm Ölçek) & 0,950 & & & & \\
\hline
\end{tabular}

Tablo 3'te de görüldüğü gibi, KMO testi sonucu \% 88,6'dır. KMO > 0,50 olduğu için veri setinin faktör analizi için uygun olduğu sonucuna varılmaktadır (Kalaycı, 2010: 322). Altı boyuttan oluşan faktör analizi toplam varyansın \%76.01'ni açıklamaktadır. Bir faktör altında büyük ağırlıkları 
olan değiş̧kenler gruplandırılmıştır. Değişkenin faktörle ilişkisinin yüksek olması, faktör ağırlı̆̆ının 0,50 ve üzeri olmasını gerektirir (Kalayc1, 2010:327-330). Bundan dolayı, faktör ağırlı̆̆ 0,50 ve üzeri olanlar dikkate alınmıştır.

ECOSERV algı ölçeği alt grupları için elde edilen faktör analizine Tablo 5 'de yer verilmiştir. Beklenti düzeyi değişkenine ilişkin faktör analizi çerçevesinde öncelikle veri setinin faktör analizi uygunluğu değerlendirilmiştir. KMO testi ve Bartlett testi sonuçları Tablo 4'te yer almaktadır.

Tablo 4. ECOSERV Beklenti Düzeyi Faktör Analizi Sonuçları

\begin{tabular}{|c|c|c|c|c|c|c|}
\hline \multirow{2}{*}{ İfadeler } & \multicolumn{6}{|c|}{ Faktörler } \\
\hline & 1 & 2 & 3 & 4 & 5 & 6 \\
\hline \multicolumn{7}{|l|}{ Ekofiziksel } \\
\hline $\begin{array}{l}\text { Ekoturizm işletmesinin çevresel bozul- } \\
\text { mayı minimize edecek ekipmanlara sa- } \\
\text { hip olması }\end{array}$ & 844 & & & & & \\
\hline $\begin{array}{l}\text { Ekoturizm işletmesinin tesislerinin çev- } \\
\text { reye uyumlu olması }\end{array}$ & 821 & & & & & \\
\hline $\begin{array}{l}\text { Ekoturizm işletmesinin çevre açısından } \\
\text { güvenli olması }\end{array}$ & 799 & & & & & \\
\hline \multicolumn{7}{|l|}{ Fiziksel } \\
\hline $\begin{array}{l}\text { Ekoturizm işletmesinin gözle görülür bir } \\
\text { albeniye sahip olması }\end{array}$ & &, 517 & & & & \\
\hline $\begin{array}{l}\text { Ekoturizm işletmesinin kirletilmemiş bir } \\
\text { çevrede konumlanmış olması }\end{array}$ & &, 589 & & & & \\
\hline $\begin{array}{l}\text { Ekoturizm işletmesinin fiziksel tesisleri- } \\
\text { nin lokal (yerel) olması }\end{array}$ & & 623 & & & & \\
\hline $\begin{array}{l}\text { Ekoturizm işletmesinin tesislerinde lokal } \\
\text { (yerel) eğlencelerin sunulması }\end{array}$ & & ,730 & & & & \\
\hline $\begin{array}{l}\text { Ekoturizm işletmesinin çalışanlarının ye- } \\
\text { rel dokuya uygun kılık kıyafetler giy- } \\
\text { mesi }\end{array}$ & &, 580 & & & & \\
\hline $\begin{array}{l}\text { Ekoturizm işletmesinin çalışanlarının k1- } \\
\text { yafetlerinin rahat olması }\end{array}$ & & 687 & & & & \\
\hline $\begin{array}{l}\text { Ekoturizm işletmesinin hizmet süreçle- } \\
\text { rinde kullanılan materyallerinin gözle } \\
\text { görülür bir şekilde cazibeli olması }\end{array}$ & &, 564 & & & & \\
\hline $\begin{array}{l}\text { Ekoturizm işletmesinin hizmet süreçle- } \\
\text { rinde kullanılan materyallerinin yerel et- } \\
\text { kilerinin olması }\end{array}$ & &, 555 & & & & \\
\hline Heveslilik & & & & & & \\
\hline $\begin{array}{l}\text { Ekoturizm işletmesinin hizmet persone- } \\
\text { linin, servisi tam olarak ne zaman sunu- } \\
\text { lacağını müşteriye söylemesi }\end{array}$ & & &, 570 & & & \\
\hline
\end{tabular}




\begin{tabular}{|c|c|c|c|c|}
\hline $\begin{array}{l}\text { Ekoturizm işletmesinin hizmet persone- } \\
\text { linin müşterilere hızlı hizmet sunması }\end{array}$ & 680 & & & \\
\hline $\begin{array}{l}\text { Ekoturizm işletmesinin hizmet persone- } \\
\text { linin her zaman müşterilere yardım et- } \\
\text { mesi }\end{array}$ & ,713 & & & \\
\hline $\begin{array}{l}\text { Ekoturizm işletmesinin hizmet persone- } \\
\text { linin hiçbir zaman müşterilerin acil ihti- } \\
\text { yaçlarını karşılayamayacak kadar meş- } \\
\text { gul olmaması }\end{array}$ & 654 & & & \\
\hline $\begin{array}{l}\text { Ekoturizm işletmesinin bir şeyi yapacak- } \\
\text { larına söz verdiklerinde söz verdikleri } \\
\text { zamanda eylemi gerçekleştirmiş olması }\end{array}$ & & ,789 & & \\
\hline $\begin{array}{l}\text { Ekoturizm işletmesinin, müşterilerinin } \\
\text { problemlerini çözmek için samimi çaba } \\
\text { göstermesi }\end{array}$ & & ,742 & & \\
\hline $\begin{array}{l}\text { Ekoturizm işletmesinin hizmetinin ilk } \\
\text { seferde en doğru şekilde sunması }\end{array}$ & & 809 & & \\
\hline $\begin{array}{l}\text { Ekoturizm işletmesinin hizmeti söz veri- } \\
\text { len zamanda sunması }\end{array}$ & & ,758 & & \\
\hline $\begin{array}{l}\text { Ekoturizm işletmesinin hatasız kayıtla- } \\
\text { rın oluşması için 1srarcı olması }\end{array}$ & & ,747 & & \\
\hline \multicolumn{5}{|l|}{ Empati } \\
\hline $\begin{array}{l}\text { Ekoturizm işletmesinin müşteriye birey- } \\
\text { sel dikkat ve özen göstermesi }\end{array}$ & & & 898 & \\
\hline $\begin{array}{l}\text { Ekoturizm işletmesinin çalışma saatleri- } \\
\text { nin tüm müşterileri için uygun olması }\end{array}$ & & &, 894 & \\
\hline $\begin{array}{l}\text { Ekoturizm işletmesinin çalışanlarının } \\
\text { müşterilere bireysel ilgi göstermesi }\end{array}$ & & &, 866 & \\
\hline $\begin{array}{l}\text { Ekoturizm işletmesinin müşterilerin kal- } \\
\text { binde en iyi etkiye sahip olması }\end{array}$ & & & 811 & \\
\hline $\begin{array}{l}\text { Ekoturizm işletmesinin çalışanlarının, } \\
\text { müşterilerin spesifik ihtiyaçlarını anla- } \\
\text { yabilmesi }\end{array}$ & & & ,778 & \\
\hline \multicolumn{5}{|l|}{ Güvence } \\
\hline $\begin{array}{l}\text { Ekoturizm işletmesinin çalışanlarının } \\
\text { müşterilerin her tip sorusuna cevap ve- } \\
\text { recek bilgiye sahip olması }\end{array}$ & & & & 619 \\
\hline $\begin{array}{l}\text { Ekoturizm işletmesinin çalışanlarının } \\
\text { davranışlarının müşterilere güven aşıla- } \\
\text { ması }\end{array}$ & & & & 600 \\
\hline $\begin{array}{l}\text { Ekoturizm işletmesinin müşterilerinin } \\
\text { işlemlerinde kendilerini güvende hisset- } \\
\text { mesi }\end{array}$ & & & &, 557 \\
\hline $\begin{array}{l}\text { Ekoturizm işletmesinin çalışanlarının } \\
\text { müşterilere karşı sürekli olarak nazik ol- } \\
\text { ması }\end{array}$ & & & & ,616 \\
\hline $\begin{array}{l}\text { Ekoturizm işletmesinin çalışanlarının } \\
\text { gerekli olan bilgileri müşterilere aktarır } \\
\text { olması }\end{array}$ & & & & ,786 \\
\hline
\end{tabular}




\begin{tabular}{|c|c|c|c|c|c|c|}
\hline $\mathrm{KMO}$ & \multicolumn{6}{|l|}{0,869} \\
\hline Bartlett & \multicolumn{6}{|c|}{$\mathrm{p}<0,05(0,000)$} \\
\hline Bartlett $x^{2}$ & \multicolumn{6}{|c|}{17938,037} \\
\hline Özdeğer & 10,174 & 5,899 & 5,250 & 2,637 & 2,364 & 1,472 \\
\hline Varyansı Açıklama Oranı \% & 33,913 & 19,662 & 17,500 & 8,792 & 7,881 & 1,574 \\
\hline Toplam Varyansı Açıklama Oranı \% & 89,322 & & & & & \\
\hline Cronbach's Alpha (Tüm Ölçek) & 0,988 & & & & & \\
\hline
\end{tabular}

Tablo 4'te de görüldüğ̈̈ gibi, KMO testi sonucu \% 86,9'dur. KMO > 0,50 olduğu için veri setinin faktör analizi için uygun olduğu sonucuna varılmaktadır. KMO > 0,50 olduğu için veri setinin faktör analizi için uygun olduğu sonucuna varılmaktadır (Kalayc1, 2010: 322). Dolayısıyla ölçeğin faktörleştirmeye uygunluk sağladığı görülmektedir. Altı boyuttan oluşan faktör analizi toplam varyansın \%89.322'sini açıklamaktadır. Bir faktör altında büyük ağırlıkları olan değişkenler gruplandırılmıştır. Değişkenin faktörle ilişkisinin yüksek olması, faktör ağırlığının 0,50 ve üzeri olmasını gerektirir (Kalaycı, 2010:327-330). Bundan dolayı, faktör ağırlığı 0,50 ve üzeri olanlar dikkate alınmıştır.

Araştırmaya katılan ekoturistlerin çevresel tutumlarını tespit etmek amacıyla kullanılan ölçek 5 ifadeden oluşmaktadır. Ölçeğe ilişkin tanımlayıcı istatistiki bilgiler Tablo 5'de gösterilmektedir.

Tablo 5. Çevresel Tutum Ölçeği Tanımlayıcı İstatistikleri

\begin{tabular}{lcc}
\hline \multicolumn{1}{c}{ Sorular } & X & Sd. \\
\hline $\begin{array}{l}\text { Kendi hayat tarzımda yaptığım küçücük değişikliklerin bile çevreyi doğru- } \\
\text { dan etkilediğini bildiğim için davranışlarıma özen gösteriyorum }\end{array}$ & 1,63 &, 48 \\
\hline Sürdürülebilir kalkınma ile ilgili faaliyetleri onaylıyorum & 1,68 &, 49 \\
\hline Her türlü çevresel faaliyette etkin görev almaktan zevk duyuyorum & 1,90 &, 70 \\
\hline $\begin{array}{l}\text { Çevre sorunlarına yönelik çalışma ve etkinliklere katılmayı vakit kaybı ola- } \\
\text { rak görüyorum* }\end{array}$ & 4,19 &, 77 \\
\hline $\begin{array}{l}\text { Bir ürünü satın alırken çevreye yönelik işaretler taşıyıp taşımadığına bak- } \\
\text { mayı alışkanlık haline getirdim }\end{array}$ & 2,02 &, 64 \\
\hline
\end{tabular}

Çevresel tutum ölçeği tanımlayıcı istatistikleri tablosu incelendiğinde bilinçli bir ekoturist profili olduğu anlaşılmaktadır. Çevresel tutuma yönelik ifadelerin cevaplarında kesinlikle katılıyorum 1, kesinlikle katılmıyorum 5 olduğu likert tipinde ortalamalar 1'e yakın bulunmuştur. “Çevre so- 
runlarına yönelik çalışma ve etkinliklere katılmayı vakit kaybı olarak görüyorum" ifadesi ters soru olarak değerlendirilmiştir ve bu yüzden ortalama değeri 5'e yakındır.

Araştırmaya katılan ekoturistlerin çevresel davranışlarını belirlemek amacıyla kullanılan ölçek 3 ifadeden oluşmaktadır. Ölçeğe ilişkin tanımlayıcı istatistiki bilgiler Tablo 6’ da gösterilmektedir.

Tablo 6. Çevresel Tutum Ölçeği Tanımlayıcı İstatistikleri

\begin{tabular}{lcc}
\multicolumn{1}{c}{ Sorular } & X & Sd. \\
\hline $\begin{array}{l}\text { "Çevre dostu" ürünleri satın alırım (ozon dostu spreyler, geri dönüşüm pa- } \\
\text { keti olan ürünler ve ekonomik boy ürünler). }\end{array}$ & 1,86 & \multirow{2}{*}{, 56} \\
\hline Doğa yürüyüşü ve geziler yaparım. & 1,89 &, 59 \\
\hline Çevre kirliliğini önlemek için düzenlenen kampanyalarda görev alırım. & 2,12 &, 71 \\
\hline
\end{tabular}

Tablo 6'daki veriler incelendiğinde ekoturistlerin tüm hayatlarında çevreci yanlarının ağır bastığı açık bir şekilde görülmektedir. Bu kişiler sadece sözle değil eylemleriyle de çevreye olan duyarlılıklarını göstermektedirler. Araştırmaya katılan ekoturistlerin çevre bilincinin yüksek olduğu görülmektedir.

\section{Araştırma Hipotezlerinin Test Edilmesi}

Araştırmanın amacına yönelik belirlenmiş olan hipotezlerin test edilmesi amacıyla korelasyon analizi gerçekleştirilmiştir. Analiz sonucunda elde edilen bilgiler ve hipotezlere ilişkin sonuçlar aşağıda tablo 7 'de gösterilmektedir.

Hipotez 1: Ekoturistlerin çevresel tutumlarn ile beklenen hizmet kalitesi arasında anlamlı bir ilişki vardır.

Araştırmaya katılan ekoturistlerin çevresel tutumları ile ECOSERV hizmet kalitesi beklenti düzeyi arasındaki ilişkinin incelendiği korelasyon analizi sonucunda, istatistiksel olarak anlamlı $(p=, 356)$ bir ilişki tespit edilememiştir. Hipotez 1 Red edilmiştir. 
Tablo 7: Hipotezlerin Testine Yönelik Korelasyon Analizi Tablosu

\begin{tabular}{|c|c|c|c|c|c|}
\hline \multicolumn{2}{|c|}{ Korelasyon Analizi } & $\begin{array}{c}\text { ECOSERV } \\
\text { Beklenti } \\
\text { Düzeyi }\end{array}$ & $\begin{array}{l}\text { ECOSERV } \\
\text { Algı Dü- } \\
\text { zeyi }\end{array}$ & $\begin{array}{l}\text { Çevresel } \\
\text { Tutum }\end{array}$ & $\begin{array}{l}\text { Çevresel } \\
\text { Davranış }\end{array}$ \\
\hline \multirow{3}{*}{$\begin{array}{l}\text { ECOSERV Bek- } \\
\text { lenti Düzeyi }\end{array}$} & Pearson & 1 &,$- 221^{* *}$ &,- 052 &, 069 \\
\hline & $\mathrm{P}$ & & ,000 & ,356 & ,226 \\
\hline & $\mathrm{N}$ & 312 & 312 & 312 & 312 \\
\hline \multirow{3}{*}{$\begin{array}{l}\text { ECOSERV } \\
\text { Alg1 Düzeyi }\end{array}$} & Pearson &,$- 221^{* *}$ & 1 &,$- 207^{* *}$ &,$- 233^{* *}$ \\
\hline & $\mathrm{P}$ & ,000 & & ,000 & ,000 \\
\hline & $\mathrm{N}$ & 312 & 312 & 312 & 312 \\
\hline \multirow{3}{*}{ Çevresel Tutum } & Pearson &,- 052 &,$- 207^{* *}$ & 1 &, $582^{* *}$ \\
\hline & $\mathrm{P}$ & ,356 &, 000 & &, 000 \\
\hline & $\mathrm{N}$ & 312 & 312 & 312 & 312 \\
\hline \multirow{3}{*}{$\begin{array}{l}\text { Çevresel Davra- } \\
\text { nış }\end{array}$} & Pearson & 069 &,$- 233^{* *}$ &, $582^{* * *}$ & 1 \\
\hline & $\mathrm{P}$ & 226 &, 000 &, 000 & \\
\hline & $\mathrm{N}$ & 312 & 312 & 312 & 312 \\
\hline
\end{tabular}

* Korelâsyon 0.05 düzeyinde anlamlıdır. **Korelâsyon 0.01 düzeyinde anlamlıdır.

Hipotez2: Ekoturistlerin çevresel tutumlarn ile algılanan hizmet kalitesi arasında anlamlı bir ilişki vardır.

Ekoturistlerin çevresel tutumları ile ECOSERV hizmet kalitesi algı düzeyi arasındaki ilişkinin incelendiği korelasyon analizi sonucunda, istatistiksel olarak anlamlı $(\mathrm{P}=, 000)$ ve negatif yönlü bir ilişki olduğu belirlenmiştir. Her ne kadar bu ilişki negatif gözükse de aslında sorular ve seçenekler dikkate alındığında pozitif bir ilişki olduğu anlaşılmaktadır. Buradaki negatiflik sorulara verilen cevapların sıralanış biçiminden kaynaklanmaktadır. Dolayısıyla ECOSERV hizmet kalitesi algı düzeyi arttıkça çevresel tutum olumlu şekilde gelişmektedir yani artmaktadır.

\section{Hipotez 3: Ekoturistlerin çevresel davranışları ile beklenen hizmet kali- tesi arasında anlamlı bir ilişki vardır.}

Araştırmaya katılan ekoturistlerin çevresel davranışları ile ECOSERV hizmet kalitesi beklenti düzeyi arasındaki ilişkinin incelendiği korelasyon analizi sonucunda, istatistiksel olarak anlamlı $(p=, 226)$ bir ilişki tespit edilememiştir. Hipotez 1 Red edilmiştir. 
Hipotez 4: Ekoturistlerin çevresel davranışları ile algılanan hizmet kalitesi arasında anlamlı bir ilişki vardır.

Ekoturistlerin çevresel davranışları ile ECOSERV hizmet kalitesi algı düzeyi arasındaki ilişkinin incelendiği korelasyon analizi sonucunda, istatistiksel olarak anlamlı $(\mathrm{P}=, 000)$ ve negatif yönlü bir ilişki olduğu belirlenmiştir. Her ne kadar bu ilişki negatif gözükse de, sorular ve seçenekler dikkate alındığında pozitif bir ilişki olduğu anlaşılmaktadır. Buradaki negatiflik sorulara verilen cevapların sıralanış biçiminden kaynaklanmaktadır. Dolayısıyla ECOSERV hizmet kalitesi algı düzeyi arttıkça çevresel tutum olumlu şekilde gelişmektedir yani artmaktadır.

\section{Değerlendirme ve Sonuç}

Farklılaşan turizm talebi ve arzın çeşitlenmesi doğrultusunda turizm kaynaklarında da farklılaşma görülmektedir. Özellikle turistlerin beklentileri farklılaşan turizm taleplerine yol açmaktadır. Kitlesel turizm hareketlerinden ziyade doğa temelli turizm çeşitleri ön plana çıkmıştır. Bu turizm çeşitlerinden biri de ekoturizm olarak hizmet vermektedir. Ekoturizm sahip olduğu turist profili kapsamında diğer turizm çeşitlerinden oldukça farklıdır. Ekoturizmi tercih eden turistlerin doğal hayatı koruma ve kollama konularına dikkat ettiği ve bilinçli oldukları görülmektedir.

Özellikle Ekoturistlerin tutum ve davranışlarının ECOSERV beklenti düzeyi ile ilişkili olduğu ve bu beklenti düzeyinin de ECOSERV algısında bir farklılığa yol açacağı düşünülmektedir. Bu beklenti düzeylerinin de onların algılarında anlamlı farklılıklara sebep olacağı değerlendirilmektedir. Değerlendirme sonuçlarında ise hem ekoturizm işletmelerine hem diğer turizm işletmelerine ve dolaylı olarak ekoturizme katkı sağlayan turizm paydaşlarına hitap eden bir çalışma olmasından ve Türkiye'de ekoturizmin literatürle ne derece uyuştuğunu ortaya koyması açısından önemlidir.

ECOSERV beklenti düzeyi ve alg1 düzeyi arasında yapılan korelasyona göre iki kavram arasında ters yönlü bir ilişki bulunmuştur. Bu ilişkiye göre beklenti düzeyi düştükçe algılama düzeyi yükselmektedir. Genel olarak beklenti düzeylerinin düşük olduğu turizm hizmeti satın alma dav- 
ranışında da algılama düzeyinin aynı oranda yüksek çıkması temel bir sonuçtur. Ayrıca Said vd., (2013) tarafından yapılan çalışmada Khan (1996) tarafından geliştirilen ECOSERV ölçeği ile ziyaretçilerin hizmet kalite beklentileri ile algılamaları arasında bir ilişki olup olmadığı incelenmiştir. Araştırma sonucunda ziyaretçilerin hizmet kalite beklentileri ile hizmet kalitesi algılamaları arasında anlamlı bir ilişki bulunmuş bu yönüyle yürütülen bu çalışma ile benzerlik göstermektedir. Said vd., (2013) çalışmalarında ziyaretçilerin beklentilerinin algılamalarından daha yüksek olduğu sonucuna ulaşılmıştır. Yürütülen bu çalışmada ise ekoturistlerin hizmet kalite beklentilerinin hizmet kalite algılamalarından daha düşük olduğu sonucu elde edildiğinden Said vd., (2013) tarafından yapılan bu çalışma ile farklılaştığı görülmüştür. Yusof vd., (2014) tarafından yapılan çalışmada SERVQUAL ölçeği ile ekoturistlerin hizmet kalite beklentileri ve algıları arasında bir ilişki olup olmadığı araştırılmış ve uygulamaya katılan ekoturistlerin hizmet kalite beklentilerinin tüm boyutlarda hizmet kalite algılamalarından yüksek olduğu sonucu elde edilmiştir. Fakat yürütülen bu çalışmada uygulamaya dâhil edilen ekoturistlerin kalite beklentilerinin algılamalarından daha düşük olduğu yönünde bulgular elde edilmiş ve Yusof vd., (2014) tarafından yürütülen çalışma ile farklılaştığ1 görülmekle bu araştırmada SERVQUAL ölçeğinin bu uygulamaya cevap verebilecek nitelikleri taşımadığ 1 vurgulanmıştır.

Ekoturistlerin çevresel davranışları ile satın almış oldukları hizmetlere ilişkin hizmet kalite beklentileri arasında bir ilişki olup olmadığını belirlemeye yönelik yapılan testlerde ekoturistlerin çevresel davranışları ile hizmet kalitesi beklentileri arasında anlamlı bir ilişki olmadığı görülmüştür.

Ekoturizm işletmelerinin özellikle ekoturistler tarafından seçilmesi bu işletmelerin rekabet etmede önemine vurgu yapmaktadır. Bunun için işletmeler özel ilgiye yönelik rekabet avantajını elde edebilmek için diğer işletmelere oranla daha farklı ve niş pazarlara yönelik hizmetler geliştirmelidirler. Çevrenin korunması; çevresel sorumluluk anlayışı, yerel kültüre zarar vermeme ve muhafazasını sağlama, ekolojik dengeyi koruma eğilimi ile sağlanmalı bunun da sürdürülebilir ekoturizm için en iyi strateji olduğu unutulmamalıdır. Ayrıca ekoturizm hizmeti veren ekoçiftlik- 
lerin tesis ve çevre kalitesi arasında uyum sağlanmalı, ekoçiftlikler arasında kalite standartlarının belirlenmesi ve tüm ekoçiftliklerin bu standartları yakalaması sağlanmalıdır.

Yürütülen bu çalışmada örneklem yerli turistlerle sinırlandırılmıştır. Daha sonraki yürütülecek olan çalışmalarda yabancı turistlerinde örneklem kütleye dâhil edilerek yerli ve yabancı ekoturistler arasındaki çevresel tutum ve davranış, hizmet kalitesi beklenti ve algısı, müşteri memnuniyeti ve değiştirme davranışlarının karşılaştırılması önerilebilir. 
EXTENDED ABSTRACT

\title{
The Relationship Between ECOSERV Service Quality Measurement Model And Environmental Attitudes And Behaviors of Ecotourists: An Application on Ecofarms
}

\author{
Zehra Türk - Fatma Çakır \\ Muğla Sıtkı Koçman University - Adnan Menderes University
}

Ecotourism activities differ mainly from traditional service measurement models in this respect, because ecotourism activities are mainly specialized in loving nature, enjoying nature, protecting and seeing environmental and cultural values, and ensuring the sustainability of the environment. Ecotourism is a concept that focuses on nature, cares about biodiversity, and enhances and sustaining local social welfare at the same time maximizing the local economic development.

The ecotourist is a tourist who is unique to the ecotourism activities that emerges with the emergence and spread of ecotourism activities. These tourists are people who are environmentally friendly, give importance to experience, respect the nature's intact nature, have a target of local language and cultural interaction and have a low cost expectation.

It can be said that ecotourists' environmental behaviors and environmental behaviors are composed of socio-demographic characteristics, ideological and political ideas, environmentally responsible behaviors and enjoyment elements. When we look at the socio-demographic characteristics of ecotourists, it is seen that they are educated at a higher degree, have higher income, and are people who do not have a liberal political idea and an obsessive idea and think that human rights are more dominant than other components of life. In addition, there was a moderate relationship between age, education, urban life and environmental attitudes. Although there is not a strong relationship between ecotourists' gender, income and professional careers, and environmental behaviors and environmental behaviors, it can be said that there is a positive relationship. It is observed that women are more sensitive to the environment than men, prefer less 
to pollute the environment, prefer products that are recyclable, but less to environmental activities than men.

The aim of the study is to determine the relationship between ecotourists' environmental attitudes and behaviors by using ECOSERV, which is the scale of service quality of ecotourism farms.

The aim of the study is to try to determine the service quality expectations and perceived service quality of the ecotourists who prefer eco farms operating in Fethiye and Ortaca districts of Muğla with the ECOSERV scale.

The universe of the research was determined as the local tourists who purchased services from eco farms (full ecotourism activity) located in Fethiye and Ortaca districts of Muğla province. The universe of the research was determined as the local tourists who purchased services from eco farms (full ecotourism activity) located in Fethiye and Ortaca districts of Muğla province. The aim of this study was to determine whether farms exhibit ecotourism activities, to provide voluntary participation to the research, to show how the farms' activity periods vary during the data collection period (on-off status) and not to meet the research subject of agricultural farms. The sample was selected from among the local ecotourists who have spent their holidays in Fethiye and Ortaca district of Muğla province.

The reliability analysis of the statements on the ECOSERV expectation scale (Cronbach's Alpha) was 0.950. The ECOSERV perception scale reliability analysis value is 0.988 . The Environmental Behavior Scale reliability analysis value is 0.801 .

Correlation analysis was performed to test the hypotheses determined for the purpose of the study.

\section{Hypothesis 1: There is a significant relationship between ecotourists' environmental attitudes and expected service quality.}

As a result of the correlation analysis between the ecotourists' environmental attitudes and the ECOSERV service quality expectation level, a statistically significant $(p=, 356)$ relationship was not found. Hypothesis 1 was rejected. 
Hypothesis 2: There is a significant relationship between ecotourists' environmental attitudes and perceived service quality.

As a result of the correlation analysis between ecotourists' environmental attitudes and ECOSERV service quality perception level, a statistically significant $(P=, 000)$ and negative relationship was determined. Although this reationship seems negative, it is understood that there is a positive relationship when considering the questions and options. Negative results arise from the order of answers to the questions. Therefore, as the level of ECOSERV service quality perception increases, the environmental attitude develops positively and thus increases.

Hypothesis 3: There is a significant relationship between ecotourists' environmental behavior and expected service quality.

As a result of the correlation analysis that examined the relationship between the environmental behaviors of the ecotourists participating in the study and the expectation level of ECOSERV service quality, a statistically significant $(p=226)$ relationship could not be determined. Hypothesis 1 was rejected.

\section{Hypothesis 4: There is a significant relationship between ecotourists' environmental behavior and perceived service quality.}

Correlation analysis between ecotourists' environmental behaviors and ECOSERV service quality perception level revealed a statistically significant $(\mathrm{P}=, 000)$ and negative relationship. Although this relationship seems negative, it is understood that there is a positive relationship considering the questions and options. The negativity here comes from the order of answers. Therefore, as the level of ECOSERV service quality perception increases, the environmental attitude develops positively and thus increases.

In the tests conducted to determine whether there is a relationship between ecotourists 'environmental behaviors and service quality expectations, it was seen that there is no significant relationship between ecotourists' environmental behavior and service quality expectations. 
The fact that ecotourism enterprises are selected by ecotourists emphasizes the importance of these enterprises for competition. In order to achieve this competitive advantage, the companies should develop services that are different and different from other enterprises. Environmental protection should be ensured by the environmental responsibility, the conservation and preservation of local culture, and the tendency to preserve the ecological balance, which should be remembered as the best strategy for sustainable ecotourism. In addition, the ecotourism service should be harmonized between the quality of the facility and the quality of the eco farms, the quality standards should be ensured between the ecotourism and all eco farms should meet these standards.

\section{Kaynakça / References}

Altan, Ş. (2006). Türkiye'de ekoturizm uygulamaları ve ekonomiye katkıları. (Yüksek Lisans Tezi), Niğde Üniversitesi, Sosyal Bilimler Enstitüsü, Niğde.

Bastič, M., ve Gojčič, S. (2012). Measurement scale for eco-component of hotel service quality. International Journal of Hospitality Management, 31(3), 1012-1020.

Demir, C., ve Çevirgen, A. (2006). Ekoturizm yönetimi. Ankara: Nobel Yayinlari.

Erdoğan, N. (2003). Çevre ve (Eko)turizm. Ankara: Genel Yayın ve Dağıtım.

Fennell, D.A. ve Nowaczek, A.M. (2003). An examination of values and environmental attitudes among ecotourists: A desciptive study involving three samples. Tourism Recreation Research, 28(1). 11-12

Goldman, D., Yavetz, B., ve Peer, S. (2006). Environmental literacy in teacher training in Israel: Environmental behavior of new students. Journal of Environmental Education, 38(1), 3-22.

Güçer, E., ve Kement, Ü. (2015). Ekoturizm kapsamında seyahat eden tüketicilerin çevreye duyarlı davranışlarının incelenmesi: Ayder örneği. Gümüşhane Üniversitesi Sosyal Bilimler Elektronik Dergisi, 6(14), 69-84.

Güngör, S. (2017). Buca kaynaklar ekoturizm potansiyeli. (Yüksek Lisans Tezi), Kâtip Çelebi Üniversitesi, Sosyal Bilimler Enstitüsü, İzmir. 
Güven, E. (2013). Çevre sorunlarına yönelik tutum ölçeğinin geliştirilmesi ve öğretmen adaylarının tutumlarının belirlenmesi. Gazi Üniversitesi Eğitim Fakültesi Dergisi, 33(2), 411-430.

Haberal, H. (2015). Turizmde alternatif ekolojik turizm-doğa turizmi kırsal turizm yayla turizmi. Ankara: Detay Yayıncilık.

Haciefendioğlu, Ş., ve Koç Ü. (2009). Hizmet kalitesi algılamalarının müşteri bağlllı̆̆ına etkisi ve fast-food sektöründe bir araştırma. Kocaeli Üniversitesi Sosyal Bilimler Enstitüsü Dergisi, 18(2), 146 - 167.

Kalayc1, Ş., (2010), SPSS uygulamalı çok değişkenli istatistik teknikleri, (5.Bask1). Ankara: Asil Yayın Dağıtım.

Kaypak, Ş. (2010). Ekolojik turizmin sürdürülebilirliği. Alanya İşletme Fakültesi Dergisi, 2(2), 93-114.

Khan, M. (1996). An examination of the service quality expectations of the ecotourist. (Doctoral Thesis), Virgina: Virginia Polytechnic Institute and State University.

Khan, M. (2003). ECOSERV ecotourists quality expectations. Annals of Tourism Research, 30(1), 109-124

Krathwohl, D. R., Bloom, B. S., ve Masia, B. B. (1973). Taxonomy of educational objectives, the classification of educational goals, handbook II: Affective Domain, New York: David McKayCo. Inc.

Kuter, N., ve Ünal, E. (2009). Sürdürülebilirlik kapsamında ekoturizmin çevresel, ekonomik ve sosyo-kültürel etkileri. Kastamonu Üniversitesi Orman Fakültesi Dergisi, 9(2), 146-156.

Kwayanti, V. (2016). Pengaruh ECOSERV terhadap destinaton image di ekowisata Mangrove Wonorejo. University of Surabaya. Faculty of Business and Economic. (Undergraduate Thesis), United Kingdom: University of Southampton.

Liu, C. H., Hong, C. Y. ve Li, J. F. (2013). The determinants of ecotourism behavioral intentions. Global Journal of Business Research, 7(4), 7184.

Nihalani, M. (2012). Eco-tourism service quality and ethical practices: A case study of tourist satisfaction on the desert triangle of rajastahn.Grin Verlag.

Nilsson, M., ve Küller, R. (2000). Travel behaviour and environmental concern. Transportation Research Part D: Transport and Environment, 5(3), 211-234. 
Noorazlan, M., Aziz., A., ve Isa, S. S. (2015). Pilot study on participation in outdoor recreation program determine perceived service quality in ecotourism services among tourists. International Journal of Administration and Governance, 1(4), 128-133

Perkins, H. E., ve Brown, P. R. (2012). Environmental values and the socalled true ecotourist. Journal of Travel Research, 51(6), 793-803.

Rivera, M. A., ve Croes, R. (2010). Ecotourists' loyalty: Will they tell about the destination or will they return? Journal of Ecotourism, 9(2), 85103.

Said, A., Shuib, A., Ayob, N., ve Yaakub, F. (2013). An evaluation of service quality from visitors'perspectives: The case of Niah National Park in Sarawak. International Journal of Business ve Society, 14(1), 61-78.

The Survey System, "Sample Size Calculator", https://www.surveysystem.com/sscalc.htm, Erişim Tarihi: 20.09.2017.

Timothy, L., ve Roh, Y. H (2004). Ecotourists satisfaction and behavioral intention. Journal Of Ecotourism and Leisure Research, 16(4), 111-130.

Timur, S., ve Yılmaz, M. (2013). Çevre davranış ölçeğinin Türkçe' ye uyarlanması. Gazi Üniversitesi Eğitim Fakültesi Dergisi, 33(2), 317-333.

Uslu, A., Akay, B., ve Ünal, A (2013). Hizmet kalitesinin ECOSERV yöntemi ile ölçülmesi: Fethiye kelebekler vadisinde bir araştırma. Seyahat ve Otel İşletmeciliği Dergisi, 10(1), 54-71.

Ünüvar, Ş. ve Aydın, M. (2017). ekoturizm destinasyonlarında hizmet kalitesinin ECOSERV ile ölçülmesi: Türkiye'deki kıyı bölgelerine yönelik bir araştırma. Van Yüzüncü Yıl Üniversitesi Sosyal Bilimler Enstitüsü Dergisi, 1(3), 1-15.

WHO, https://www.wto.org/ Erişim Tarihi: 12 Eylül 2017.

Yusof, N., Rahman, F.A., Jamil, M.F.C ve Iranmanesh, M. (2014). measuring the quality of ecotourism services: Case study-based model validation. Sage Open, 4(2), 1-9.

Yücel, C. (2002) Turizmde yükselen değer: Ekoturizm. https://www.tursab.org.tr/dosya/1023/02nieko_1023_1889046.pdf Erişim Tarihi: 23 Eylül 2017. 


\section{Kaynakça Bilgisi / Citation Information}

Türk, Z. ve Çakır, F. (2019). ECOSERV hizmet kalitesi ölçüm modeli ile ekoturistlerin çevresel tutum ve davranışları arasındaki ilişki: Ekoçiftliklerde bir uygulama. OPUS-Uluslararası Toplum Araştırmaları Dergisi , 10(17), 226-256. DOI: 10.26466/opus. 505950 